\title{
Genome sizes of Eucomis L'Hér. (Hyacinthaceae) and a description of the new species Eucomis grimshawii G.D.Duncan \& Zonneveld
}

\author{
B. J. M. Zonneveld • G. D. Duncan
}

Received: 25 June 2009/ Accepted: 9 October 2009/Published online: 10 December 2009

(C) The Author(s) 2009. This article is published with open access at Springerlink.com

\begin{abstract}
Nuclear genome size, as measured by flow cytometry with propidium iodide, was used to investigate the relationships within the genus Eucomis L'Hér. (Hyacinthaceae). Most species of Eucomis have the same basic chromosome number, $x=15$. However, the somatic DNA $2 \mathrm{C}$-value (2C) is shown to range from 21 to $31 \mathrm{pg}$ for the diploids. The largest genome contains roughly $10^{10}$ more base pairs than the smallest. Genome sizes are evaluated here in combination with available morphological and geographical data. Therefore, the taxonomy proposed here is not based on genome size alone. The genus Eucomis, as here determined, has 12 species. These can be divided into two groups: mainly dwarf diploid species and large-sized, tetraploid species. A small diploid plant, Eucomis (autumnalis subsp.) amaryllidifolia, is restored to species status, as a diploid subspecies seems incongruent with an allotetraploid Eucomis autumnalis. Moreover, as a diploid it is separated reproductively from the allotetraploid E. autumnalis. A new diploid species that has the lowest $\mathrm{C}$ value, E. grimshawii, is described here. On the basis of DNA content and other morphological characters, possible parents are suggested for all tetraploid species. Nuclear DNA content as measured by using flow cytometry may
\end{abstract}

B. J. M. Zonneveld ( $\bowtie)$

Nationaal Herbarium Nederland, Universiteit Leiden Branch, P.O. Box 9514, 2300RA Leiden, The Netherlands

e-mail: Zonneveld@NHN.Leidenuniv.nl

G. D. Duncan

South African National Biodiversity Institute, Kirstenbosch

Botanical Garden, Private Bag X7, Claremont 7735,

Cape Town, South Africa conveniently be used to produce systematic data. It is applicable even in dormant bulbs or sterile plants for the monitoring of the trade in bulbous species.

Keywords Eucomis grimshawii sp. nov ·

Eucomis species · DNA 2C-value · Taxonomy

\section{Introduction}

Eucomis, a small genus of 12 species in the family Hyacinthaceae, is endemic to the southern African countries, South Africa, Botswana, Lesotho, and Swaziland, as well as Zimbabwe and Malawi in southern Tropical Africa (Duncan 2007). The first described species (now known as E. regia) was illustrated in the early eighteenth century in Hortus Ethamensis (Dillenius 1732). Five of the later species were described by Baker (1878, 1886, 1887, 1895), and the most recently described one was E. schijffii (Reyneke 1976). Eucomis is characterized by the presence of a coma or tuft of leaf-like bracts that develop above the inflorescence. The most recent classification of Eucomis (Reyneke 1972) recognized ten species based on morphological characters, namely E. autumnalis (Mill.) Chitt., E. bicolor Baker., E. comosa (Houtt.) Wehrh., E. humilis Baker, E. montana Compton, E. pallidiflora Baker, E. regia (L.) L'Hér., E. schijffii Reyneke, E. vandermerwei Verd. and E. zambesiaca Baker. In the World Checklist for Eucomis (Govaerts 2006), 33 names were listed, and Reyneke's 10 species and 3 subspecies were accepted there. The present study follows Reyneke's ten recognised species and in addition restores E. amaryllidifolia Baker to species level and describes the new species E. grimshawii G.D.Duncan \& Zonn. The species are here divided into two groups: seven mainly small-sized diploids $(2 n=2 x=30)$ 
and five large-sized tetraploids $(2 n=4 x=60)$ (Reyneke and Liebenberg 1980).

Eucomis regia (L.) L'Hér. was the first Eucomis to be cultivated in Britain close to 3 centuries ago, but the species that have featured most prominently in hybridization and selections have been the fully hardy E. comosa (Houtt.) Wehrh. (syn: E. punctata L'Hér.) and E. autumnalis (Mill.) Chitt. (syn: E. undulata Aiton), as well as the less hardy, tall-growing E. pallidiflora Baker.

All the species are summer-flowering with the single exception of E. regia, which hails from the winter rainfall zone (Duncan 2007).

In South Africa the bulbs of several species, particularly E. autumnalis, are used in traditional medicine to treat a number of diseases. Recent investigations have validated this use by finding that extracts of Eucomis contain a high COX-1 inhibitory activity (Taylor and van Staden 2001). Within the bulb trade, the dwarf species have potential as flowering pot plants and the larger members as cut flowers. The only drawback to the appeal of certain species is the foulsmelling flowers (especially E. bicolor Baker, E. humilis Baker, E. schijffii Reyneke and E. vandermerwei Verd.).

The only comprehensive taxonomic treatment of the genus remains that of W.F. Reyneke, in the form of an unpublished M.Sc. thesis produced in South Africa in 1972. J. Compton wrote an excellent account of the genus (1990), and the present article could be regarded as an extension and DNA-based backing to these treatises.

To elucidate the relationships between Eucomis species, the classical taxonomic traits based on morphological characters and geographical distribution are here supplemented with data on nuclear DNA content. These were not investigated earlier in the systematic study of Eucomis. Taxonomy of Eucomis is rather difficult as the flowers are very similar. The main useful characters are fragrance, plant size and leaf color. More than 80 different accessions representing all accepted species were measured in an attempt to understand the relationships within Eucomis better.

Nuclear DNA content can conveniently be measured by flow cytometry using propidium iodide, a stoichiometric DNA stain that intercalates in the double helix. Where many species in a genus have the same chromosome number, differences in DNA 2C value have proven to be very effective in delimiting infrageneric divisions in a number of taxa (Ohri 1998). Greilhuber $(1998,2005)$ has clearly shown that intraspecific variation of genome size is much less than assumed.

The evolution of genome size [Cx-value (Greilhuber 1979)] has received increased attention during recent years. Primitive angiosperms are now supposed to have had small genomes; increases up to a factor of 1,000 have occurred independently in various modern taxa (Leitch et al. 1998). Flow cytometry was successfully used to measure the
2C-value for the genera Hosta Tratt., Helleborus L., Clivia Lindl., Nerine Herb., Agapanthus L'Hér., Galanthus L., Narcissus L., Gasteria Duval., Tulipa L., etc., by Zonneveld (2003, 2008, 2009), Zonneveld and Van Iren (2001), Zonneveld and Duncan (2003, 2006), Zonneveld and Van Jaarsveld (2005) and Zonneveld et al. (2003). In this paper it is shown that genome size alone is not sufficient to discriminate all species of Eucomis. Also one subspecies is returned to species status, and a new species is described.

\section{Materials and methods}

\section{Plant material}

Plant material was obtained mainly from the collections of Kirstenbosch Botanical Garden, J. des Brisay (UK), C. McMaster (RSA) and J. Grimshaw (UK). Where possible, material of known wild origin was used, and care was taken to ensure correct identification of all material. Vouchers of material from the Kirstenbosch and McMaster collections (including all known species) are lodged in the Compton Herbarium at Kirstenbosch, Cape Town, RSA.

\section{Flow cytometric measurement of DNA $2 \mathrm{C}$ value}

For the isolation of nuclei, about $5 \mathrm{~cm}$ of root was chopped together with a piece of Agave americana L. 'Aureomarginata' as an internal standard (see below). The chopping was done with a new razor blade in a Petri dish in $0.25 \mathrm{ml}$ nucleiisolation buffer to which $0.25 \mathrm{mg} \mathrm{RNase} / \mathrm{ml}$ was added (Zonneveld and Van Iren 2001). After adding $1.75 \mathrm{ml}$ propidium iodide solution (50 $\mathrm{mg} \mathrm{PI} / \mathrm{l}$ in isolation buffer), the suspension with nuclei was filtered through a $30-\mu \mathrm{m}$ nylon filter. The fluorescence of the nuclei was measured $1 / 2 \mathrm{~h}$ and 1 $\mathrm{h}$ after addition of propidium iodide, using a Partec CA-II flow cytometer. The optical path contained a HBO mercury lamp, filters KG1, BG12, dichroic mirror TK500, filter OG570 and a Leitz $50 \times 1$ water immersion objective. Data were analyzed by means of DPAC software (Partec GmbH). The 2C DNA content of the sample was calculated as the sample peak mean, divided by the Agave peak mean, and multiplied with the amount of DNA of the Agave standard. At least three different samples, each with at least 5,000 nuclei, were measured twice for each clone. Most histograms revealed a coefficient of variation of less than $5 \%$. The standard deviation was calculated for the DNA content of each species, using all relevant measurements.

Internal standard and absolute DNA content values

When measuring nuclear DNA content by means of flow cytometry, it is necessary to chop tissue from the plant of 
interest together with an internal standard: this standard must be as close as possible to the plants of interest. In this way, variation in signal intensities due to staining kinetics, to light absorption and quenching by sample components, as well as to instrument and other variables, is reduced to a minimum. Agave americana was chosen as internal standard for Eucomis. Agave americana is available year round, does not mind several weeks without water and, being a large plant, a single specimen can serve a lifetime, thereby further reducing variation in readings. It also has a low background in propidium iodide measurements and shows a single $G_{0}$ peak, almost lacking $G_{2}$ arrest.

Fresh male human leucocytes $(2 \mathrm{C}=7.0 \mathrm{pg} ; 1 \mathrm{pg}=$ $10^{-12} \mathrm{~g}=0.978 \times 10^{9}$ base pairs; Dolezel et al. 2003) were chosen as primary standard (Tiersch et al. 1989). This yields $2 \mathrm{C}=15.9 \mathrm{pg}$ for nuclei of Agave americana L. Based on a published male human genome size of $6.294 \times 10^{9}$ base pairs, the nucleus was calculated as containing 6.436 pg (Dolezel et al. 2003). However, this is based on a human sequence where the size of the very large repeat sequences could not accurately be determined. So in the end, the genome size could be closer to $7 \mathrm{pg}$ than now envisioned.

\section{Results}

\section{General}

Eucomis leaves, like most members of the Hyacinthaceae, produce a lot of mucus when cut, clogging the flow cytometer. Therefore, nuclei of Eucomis were extracted from the thicker roots. Remarkable was the high content of root nuclei with a doubled DNA content. Usually between 25-50\% nuclei are found in roots in most genera investigated (Zonneveld, unpublished) that have doubled their DNA content by endopolyploidy. However, in both diploid and tetraploid Eucomis between 50 and up to $75 \%$ of the nuclei are found to have doubled their nuclear DNA content (Fig. 1). Five of the diploid species hardly differ in DNA 2C value, and the same is true for the tetraploid species. The main morphological distinctions between the species are fragrance, the presence or absence of a purple color to the leaf base or flower, the cylindrical or clavate shape of the scape and overall plant size.

The diploid species

\section{E. schijffii Reyneke}

A dwarf native of the Drakensberg of KwaZulu-Natal and Lesotho, and the mountains of the southern Eastern Cape, it is the Eucomis species with the highest altitudinal limit,

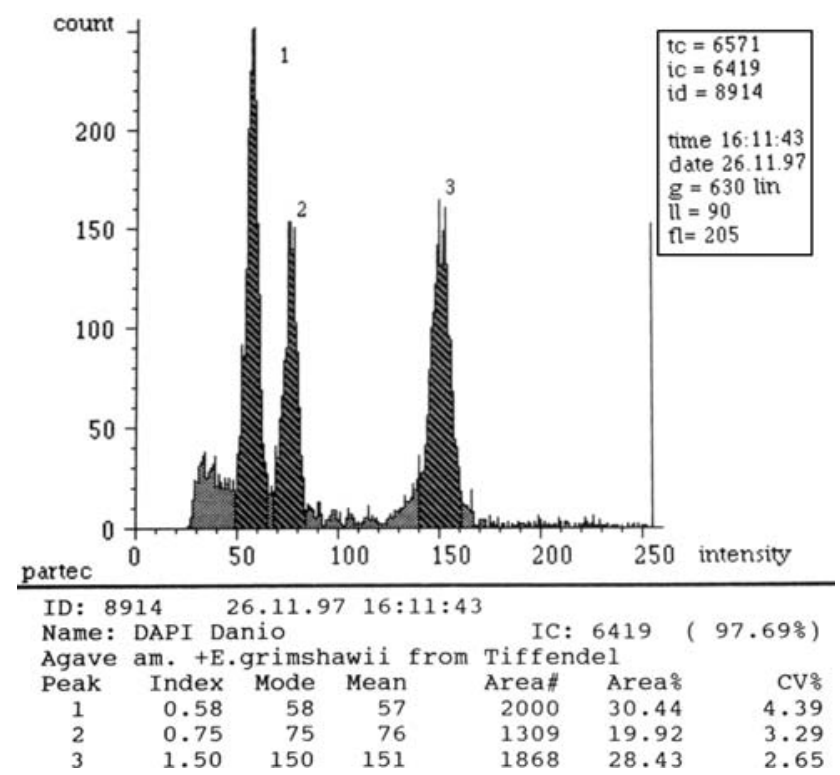

Fig. 1 Flow cytometry histogram of fluorescence intensity of more than 6,000 nuclei isolated and stained simultaneously. Peak 1 the nuclei of the standard: Agave americana $(15.9 \mathrm{pg}) .2$ The diploid nuclei of the roots of Eucomis grimshawii (21.2 pg). 3 The 59\% nuclei with a tetraploid amount of nuclear DNA of the roots of Eucomis grimshawii (42.1 pg)

occurring at up to $3,200 \mathrm{~m}$. The rosette has intensely bluish-grey leaves with maroonish undersides. The purplish leaf margins are minutely toothed. The plant grows to $15 \mathrm{~cm}$ high, the coma bracts are large, sometimes overhanging the inflorescence, and its purplish-maroon flowers emit a strong, fetid scent. It has clavate, purple scapes, and its DNA $2 \mathrm{C}$ value is $22.8 \mathrm{pg}$.

\section{E. vandermerwei Verd.}

This dwarf species reaching up to $24 \mathrm{~cm}$ high in flower is restricted to rocky outcrops in the grassland at high altitude in Mpumalanga in northeastern South Africa (Verdoorn 1944). Its brownish-maroon flowers are extremely long lasting, it has cylindrical scapes, and the plant has cryptically marked foliage. It has a fetid smell, and its DNA 2C value is $23.5 \mathrm{pg}$.

\section{E. zambesiaca Baker}

Occurring in the northern parts of South Africa's Limpopo Province and in the highlands of Malawi and Zimbabwe, this species has creamy-white, sweet-scented racemes that mature to bright green and cylindrical scapes. Reaching $30 \mathrm{~cm}$ high, it flowers from mid to late summer. The leaves are always uniformly pale green, and it is a variable species as regards inflorescence width; in some forms these can be as narrow as $15 \mathrm{~mm}$. Its DNA 2C-value is $23.3 \mathrm{pg}$. 
Eucomis grimshawii G.D.Duncan \& Zonn., sp. nov.

Haec species habitu E. schijffii similis sed foliis leviter viridibus, margine cartilagineo, floribus albovirentibus, parvioribus, breviviventibus, suaveolentibusque, filamentis triangularibus, antheribus parvis, polline cremeo, fructibus et ovariis valde inflatis differt.

Type: South Africa, Eastern Cape, 3027 (Lady Grey): Hill below Tiffendel Ski Resort north of Rhodes, on shaded moist, grassy, south and southwest facing slopes, under overhanging rocks near a stream (-DD) Dec 2008, J.C. McMaster s.n. (NBG, holo.!) (see Fig. 2).

Dwarf geophyte, deciduous, summer-growing, 80$100 \mathrm{~mm}$ high. Bulb ovoid, $35-40 \times 25 \times 30 \mathrm{~mm}$ solitary or offset-forming, scales cream, apices obtuse; tunic 1- or 2-layered, membranous, pale brown; cataphyll oblong, $30-40 \times 10-12 \mathrm{~mm}$, translucent white, subterranean, adhering to leaf bases, apex obtuse. Leaves 4 or 5, broadly lanceolate, $90-120 \times 40-60 \mathrm{~mm}$, spreading to suberect, pale green, longitudinal veins prominent on upper surface, depressed, 5-7 mm apart; midrib prominent on lower surface, yellowish green; margins cartilaginous, flat to weakly undulate, hyaline. Inflorescence few to many flowered, 30-50 mm long, erect, dense; scape clavate, 50-60 $\times$ 10-15 mm, erect, pale green, lower half heavily flushed with deep maroonish-magenta, upper half sporadically spotted or blotched with maroonish-magenta; rachis pale green; fertile bracts lanceolate, slightly canaliculate, lengthening towards inflorescence apex, 5-15 × 2-5 mm. Perianth campanulate, weakly sweet-scented, spreading, nectar sweet; lower flowers sessile, pedicels of upper flowers up to $1 \mathrm{~mm}$ long; tepals oblong, 3-5 × 3-4 mm, greenish white, curved inwards, soft, short-lived; sterile coma bracts 9-16, broadly lanceolate to ovate, $15-35 \times 10-25 \mathrm{~mm}$, pale green,

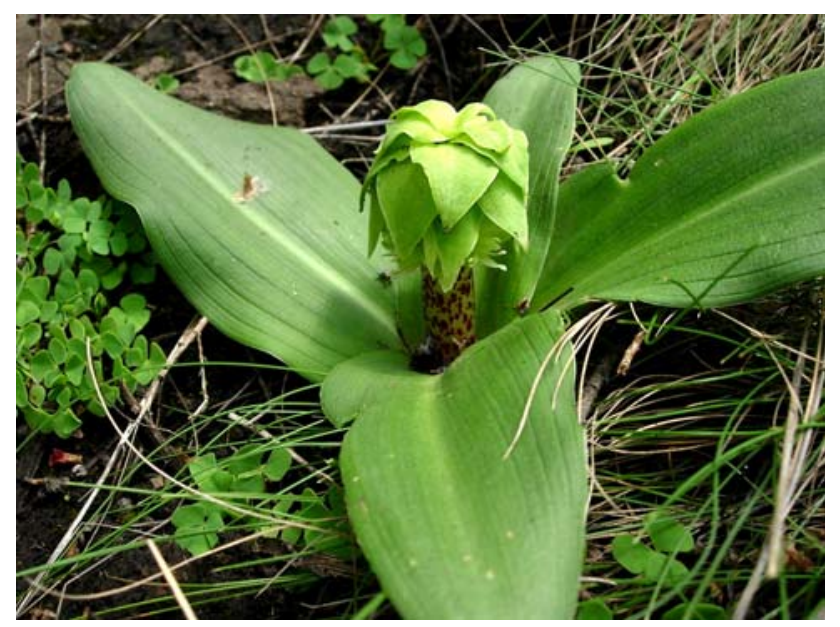

Fig. 2 Eucomis grimshawii G.D.Duncan \& Zonn. sp. nov. as photographed 29 December 2006 at Tiffendell, Eastern Cape, South Africa by C. McMaster suberect to spreading or weakly deflexed, often obscuring upper flowers; margins cartilaginous, hyaline. Stamens 6, included; filaments narrowly triangular $3-4 \times 0.2-1 \mathrm{~mm}$, white, curved inwards; anthers oblong, $1.5 \times 0.8 \mathrm{~mm}$, pollen cream. Ovary trilocular, bright green; locules more or less ovoid, 4-5 $\times 4-5 \mathrm{~mm}$, strongly inflated; style weakly decurved, pale green, 3-4 mm long, stigma penicillate. Capsule flat-topped, membranous, dehiscent, pale brown, ripening rapidly; locules strongly inflated, $7-10 \times$ 10-15 mm. Seed ovoid, 3-3.5 × $2.5 \mathrm{~mm}$, dull blackish brown, 2 or 3 per locule, surface sculpturing reticulate.

Note

It is the smallest species in the genus, and with $21.1 \mathrm{pg}$ it also has the lowest amount of nuclear DNA of them all and might therefore be the most plesiomorphic one. However, we have no further arguments to substantiate this claim. Four accessions of E. grimshawii were measured. They differed consistently about $7 \%$ in nuclear DNA content, this despite the fact that they were morphologically indistinguishable. It cannot be excluded that aneuploidy was involved.

\section{Distribution and habitat}

Eucomis grimshawii was discovered in 2002 by Dr. J. Grimshaw at Tiffendel Ski Resort, north of Rhodes Hamlet, Southern Drakensberg, just south of Lesotho between 2,720 and 2,740 m altitude. The plant was subsequently found by J.C. McMaster at the same locality and close by at Naude's Nek Pass to the northeast. They grow in shaded, seasonally wet, south-facing grassy slopes below overhanging rocks, in rich, heavy black soil. They are also encountered in boggy conditions, growing in shade in association with Kniphofia caulescens and $K$. northiae (Grimshaw, pers. comm.).

The species is most similar to E. schijffii. The latter differs in its intensely glaucous leaves with strongly cartilaginous, minutely crisped purple margins. It is further a taller plant (10-15 cm high) with a purple scape. The tepals are dark purple (instead of greenish white), longlasting (8-9 days instead of 2-3) and firm (instead of soft), and the flowers emit a strong fetid scent (instead of sweet). Its filaments are purple (instead of white) and broadly triangular with 2-mm-wide bases and have larger anthers $(2.5 \times 1.5 \mathrm{~mm})$ with bright yellow pollen (instead of cream). Its ovary is much less inflated, has prominent apical grooves, and the capsule with a purple pericarp is also much less inflated, and takes 2 months to ripen (instead of 3-4 weeks). The two species are unusual within the genus in having dull blackish brown seeds with reticulate sculpturing (instead of glossy and smooth). 
Eucomis schijffi grows in moist terrain on exposed basalt cliffs and in open rocky, grassy fields, and has a wider distribution along the Lesotho/KwaZulu-Natal border, in northern and southern Lesotho and in the mountains of the southern part of the Eastern Cape (Reyneke 1976). It has a longer flowering period extending from late November to late February.

\section{Eucomis amaryllidifolia Baker}

In the type description (Baker 1878) E. amaryllidifolia has a leaf length of $30-37 \mathrm{~cm}$ and a slightly shorter inflorescence. It is a plant from the Eastern Cape and only differs from E. autumnalis in its much narrower leaves of $3 \mathrm{~cm}$. However, it must be kept in mind that this was a plant cultivated in a greenhouse in England. This might explain the seemingly larger size in the type description. One of the authors (G.D.) has never seen a long and narrow leaved plant of this species in nature or in culture. It was later reassessed as a subspecies of E. autumnalis as E. autumnalis subsp. amaryllidifolia (Baker) Reyneke, restricted to the Eastern Cape and Free State in South Africa (Reyneke 1980). In the description of Reyneke (1980), it is a small plant with a leaf length of $13-30 \mathrm{~cm}$, a clavate scape and an inflorescence of only $3-7 \mathrm{~cm}$. The tetraploid chromosome count that was found for a "subsp. amaryllidifolia" from Fauresmith, Free State, is most likely a different subspecies (Reyneke and Liebenberg 1980), probably subsp. clavata. In describing the subspecies of E. autumnalis, four taxa are actually mentioned by Reyneke (1980). Going from south to north in RSA, they are (1) a smaller subsp. autumnalis from the south (Eastern Cape), (2) subsp. clavata (widespread in north and northeast of South Africa), (3) subsp. amaryllidifolia (Eastern Cape) and (4) a larger subsp. autumnalis from the north (KwaZulu-Natal and Limpopo provinces in South Africa, and Zimbabwe, but not Malawi).

Eucomis autumnalis subsp. autumnalis and subsp. clavata have a tetraploid amount of nuclear DNA (Tables 1, 2). All plants measured here as subsp. amaryllidifolia were small, diploid plants with on average $23.4 \mathrm{pg}$ and came from the south, i.e., Eastern Cape. Reyneke and Liebenberg (1980) concluded also that all tetraploids were allotetraploid, based on the absence of identical chromosome pairs for the large chromosomes. However, if a diploid is considered as incongruent as a subspecies of an allotetraploid, then Eucomis amaryllidifolia is a good species. Moreover, as a diploid it is separated reproductively from the allotetraploid E. autumnalis. Therefore, it seems best to consider the large tetraploid form as subsp. autumnalis with or without a narrow leaf and restore the small diploid form as E. amaryllidifolia.

\section{Eucomis bicolor Baker}

The well-known and very hardy E. bicolor frequents various high-altitude habitats from the northern part of the Eastern Cape to KwaZulu-Natal, Lesotho and southern Mpumalanga. The name E. reichenbachii that has crept into some nursery lists is a mistake and is in fact $E$. bicolor. E. bicolor is the only diploid that has a large size. It has a fetid smell, cylindrical scapes and often a purple base to the leaves. Its amount of nuclear DNA of $25.7 \mathrm{pg}$ deviates from that of the other diploids.

\section{Eucomis regia (L.) L'Hér.}

Eucomis regia is native to the winter rainfall zone of the Northern and Western Cape. This rather variable plant is confined to heavy clay soil in open aspects or between large rocks or low bushy cover. The bulbs are usually solitary, and the uniformly green leaves lie flat on the ground or spread over rocks. The inflorescence reaches up to $20 \mathrm{~cm}$ high. In some specimens the leafy bracts of the coma are disproportionately large, almost completely obscuring the green, unpleasant-smelling flowers. It has clavate scapes and is the only Eucomis that flowers from late winter to late spring. It has a rather deviating amount of nuclear DNA with $31.3 \mathrm{pg}$. It is unclear if there is any relationship between the differences in flowering time and amount of DNA for this species.

\section{The tetraploid species}

\section{Eucomis autumnalis (Mill.) Chitt.}

By far the most widespread Eucomis is the greenish-cream flowering E. autumnalis. Eucomis autumnalis leaves have undulate edges (Chittenden 1951) and according to Reyneke (1980) it comprises three subspecies: subsp. autumnalis, subsp. clavata and subsp. amaryllidifolia. Eucomis amaryllidifolia Baker from the Eastern Cape is here considered as a separate, diploid species. However, the diploid is apart from its overall size very similar to the tetraploid, 'southern' forms of subsp. autumnalis, the flowers differing only in their shorter tepals $(6-8 \mathrm{~mm}$ long). Reyneke and Liebenberg (1980) consider all tetraploids as likely allotetraploids based on the fact that none has identical chromosome pairs. If that is accepted, an allotetraploid E. autumnalis cannot be derived solely from a doubling of the diploid E. amaryllidifolia.

The subsp. autumnalis has a cylindrical scape and semierect leaves, occurring in open grassland in the Eastern Cape, KwaZulu-Natal and Limpopo provinces of South Africa, and in Zimbabwe. It includes naturally occurring 
Table 1 Eucomis accessions with their 2C amount of DNA per nucleus, average, standard deviation (SD), locality and origin

\begin{tabular}{|c|c|c|c|c|c|}
\hline Species & DNA in pg & Average & SD & Locality & Origin \\
\hline \multicolumn{6}{|l|}{ Diploid species } \\
\hline Eucomis grimshawii Duncan \& Zonn. sp. nov. & 22.5 & 21.1 & 1.0 & Tiffendell E.Cape, A & J. Grimshaw s.n. \\
\hline Eucomis grimshawii Duncan \& Zonn. sp. nov. & 21.2 & & & Tiffendell E.Cape, A & J. Grimshaw s.n. \\
\hline Eucomis grimshawii Duncan \& Zonn. sp. nov. & 20.5 & & & Tiffendell E.Cape, B. & C. McMaster s.n. \\
\hline Eucomis grimshawii Duncan \& Zonn. sp. nov. & 20.3 & & & Tiffendell E.Cape, B. & C. McMaster s.n. \\
\hline Eucomis schijffii Reyneke & 22.7 & 22.8 & 0.4 & Drakensberg, KZN & van Jaarsveld 6551 \\
\hline Eucomis schijffii Reyneke & 22.8 & & & Sani Pass KZ Natal & J. Grimshaw s.n. \\
\hline Eucomis schijffii Reyneke & 22.9 & & & Sani Pass KZ Natal & J. Grimshaw s.n. \\
\hline Eucomis zambesiaca Baker & 22.7 & 23.3 & 0.6 & Hort. & G. Duncan \\
\hline Eucomis zambesiaca Baker & 23.4 & & & Hort. & Longwood Grds. \\
\hline Eucomis zambesiaca Baker & 23.8 & & & Hort. & J. des Brisay \\
\hline Eucomis vandermerwei Verd. & 23.2 & 23.5 & 0.6 & Hort. & J. Agoston \\
\hline Eucomis vandermerwei Verd. & 23.3 & & & Dullstroom, Mpumal. & H. de Lange s.n. \\
\hline Eucomis vandermerwei Verd. & 23.9 & & & Hort. & J. des Brisay \\
\hline Eucomis vandermerwei Verd. & 23.5 & & & Middelburg, Mpumal. & McDonald \\
\hline Eucomis bicolor Baker & 26.1 & 25.7 & 0.6 & Harrismith, Free State & B. Szabo 197 \\
\hline Eucomis bicolor Baker & 25.1 & & & Cathedral Peak KZN & L. van der Walt s.n. \\
\hline Eucomis bicolor Baker & 25.1 & & & Drakensberg, KZN & NBG 221/76 \\
\hline Eucomis bicolor Baker & 26.3 & & & Hort. & J. des Brisay \\
\hline Eucomis bicolor Baker & 25.4 & & & Hort. & J. des Brisay \\
\hline Eucomis bicolor 'Reichenbachii' & 25.8 & & & Hort. & J. des Brisay \\
\hline Eucomis bicolor 'Reichenbachii' & 25.4 & & & Hort. & J. des Brisay \\
\hline Eucomis bicolor 'Alba' & 26.0 & & & Hort. & J. des Brisay \\
\hline Eucomis bicolor 'White' & 26.2 & & & Hort. & J. des Brisay \\
\hline Eucomis bicolor (as sp. Jack Elliot) & 26.0 & & & Hort. & J. des Brisay \\
\hline E. regia (L.) L’Hér. & 30.4 & 31.3 & 1.0 & Nieuwoudtville, N.Cap & R. Saunders s.n. \\
\hline E. regia (L.) L’Hér. & 32.0 & & & Napier, W.Cape & G. Duncan s.n. \\
\hline E. regia (L.) L’Hér. & 32.1 & & & Caledon, W. Cape & G. Duncan 466 \\
\hline E. regia (L.) L’Hér. & 30.6 & & & Dassiesfontein, W.C. & J. Grimshaw s.n. \\
\hline E. regia (L.) L’Hér. & 31.4 & & & Hort. & J. des Brisay \\
\hline Eucomis amaryllidifolia Baker & 22.9 & 23.4 & 0.3 & Kinross, E.Cape & C. McMaster s.n. \\
\hline Eucomis amaryllidifolia Baker & 22.6 & & & Bombazi, E.Cape & C. McMaster s.n. \\
\hline Eucomis amaryllidifolia Baker & 23.5 & & & Quagga Heights, E.C & C. McMaster s.n. \\
\hline Eucomis amaryllidifolia Baker & 23.5 & & & Stutterheim, E. Cape & C. McMaster s.n. \\
\hline Eucomis amaryllidifolia Baker & 23.2 & & & Bedford, E. Cape & C. McMaster s.n. \\
\hline Eucomis amaryllidifolia Baker & 23.2 & & & Bedford, E. Cape & C. McMaster s.n. \\
\hline Eucomis amaryllidifolia Baker & 23.3 & & & Hort. & J. des Brisay \\
\hline Eucomis amaryllidifolia 'White Dwarf' & 24.0 & & & Hort. & J. des Brisay \\
\hline Eucomis amaryllidifolia Baker & 24.2 & & & Hort. & J. des Brisay \\
\hline \multicolumn{6}{|l|}{ Tetraploid species } \\
\hline Eucomis autumnalis (Mill.) Chitt. & 47.2 & 47.6 & 1.0 & Triple Streams, E.C. & J. des Brisay \\
\hline Eucomis autumnalis (Mill.) Chitt. & 48.1 & & & Sherwood, KZN & J. des Brisay \\
\hline Eucomis autumnalis (Mill.) Chitt. & 49.7 & & & Baakens Valley, E.C & J. des Brisay \\
\hline Eucomis autumnalis (Mill.) Chitt. & 47.1 & & & Wakkerstroom, Mpu. & J. des Brisay \\
\hline Eucomis autumnalis (Mill.) Chitt. & 48.4 & & & Hort. & J. des Brisay \\
\hline Eucomis autumn. (Mill.) Chitt. ssp. autumnalis & 46.5 & & & Triple Streams, E.C. & C. McMaster s.n. \\
\hline Eucomis autumn. (Mill.) Chitt. ssp. autumnalis & 47.5 & & & Kirstenbosch BG & NBG $671 / 83$ \\
\hline Eucomis autumn. (Mill.) Chitt. ssp. autumnalis & 47.8 & & & Aliwal North, E.Cape & C. McMaster s.n. \\
\hline
\end{tabular}


Table 1 continued

\begin{tabular}{|c|c|c|c|c|c|}
\hline Species & DNA in $\mathrm{pg}$ & Average & SD & Locality & Origin \\
\hline Eucomis autumn. (Mill.) Chitt. ssp. autumnalis & 47.7 & & & Nieu Bethesda, E.C. & C. McMaster s.n. \\
\hline Eucomis autumn. (Mill.) Chitt. ssp. autumnalis & 47.6 & & & Egglestone, E. Cape & C. McMaster s.n. \\
\hline Eucomis autumn. (Mill.) Chitt. ssp. autumnalis & 45.5 & & & Katberg, E. Cape & C. McMaster s.n. \\
\hline Eucomis autumn. (Mill.) Chitt. ssp. autumnalis & 46.0 & & & Drakensberg; 'Purple' & G. Duncan s.n. \\
\hline Eucomis autumnalis ssp. clavata (Baker) Reyneke & 47.2 & 46.9 & & Oxbow, Lesotho & G. Matthews 870 \\
\hline Eucomis autumnalis ssp. clavata (Baker) Reyneke & 46.2 & & & Port Edward, KZN & D. Govender 42 \\
\hline Eucomis autumnalis ssp. clavata (Baker) Reyneke & 47.3 & & & Qwa Qwa, Free State & D. Govender 40 \\
\hline Eucomis pallidiflora Baker ssp. pallidiflora & 48.1 & 47.7 & 1.2 & Kirstenbosch BG & NBG 63/09 \\
\hline Eucomis pallidiflora Baker ssp. pallidiflora & 46.3 & & & Wakkerstroom, Mpu. & C. McMaster s.n. \\
\hline Eucomis pallidiflora Baker ssp. pallidiflora & 48.3 & & & Hort. & J. des Brisay \\
\hline Eucomis pallidiflora Baker ssp. pallidiflora & 48.3 & & & Hort. & R. MacKenzie \\
\hline E. pallidiflora ssp. pole-evansii (N.E.Br.) Reyneke & 45.9 & 46.4 & & Hort. & J. Grimshaw \\
\hline E. pallidiflora ssp. pole-evansii (N.E.Br.) Reyneke & 46.2 & & & Hort. & J. Agoston \\
\hline E. pallidiflora ssp. pole-evansii (N.E.Br.) Reyneke & 47.2 & & & Hort. & J. des Brisay \\
\hline Eucomis comosa (Houtt.) Wehrh. var. comosa & 48.0 & 48.6 & 1.0 & Kirstenbosch BG & NBG 818/89 \\
\hline Eucomis comosa (Houtt.) Wehrh. var. comosa & 48.7 & & & Port Edward, KZN & D.Govender 56a \\
\hline Eucomis comosa (Houtt.) Wehrh. var. comosa & 49.1 & & & Mnt Kubusi, E. Cape & C. McMaster s.n. \\
\hline Eucomis comosa (Houtt.) Wehrh var. striata & 61.0 & 61.0 & 1.9 & Hort. & J. des Brisay \\
\hline Eucomis humilis Baker & 48.9 & 47.8 & 0.7 & Drakensberg, KZN & D. Human s.n. \\
\hline Eucomis humilis Baker & 48.0 & & & Drakensberg, KZN & D. Human s.n. \\
\hline Eucomis humilis Baker & 46.6 & & & Qwa Qwa, Free State & D. Govender 39 \\
\hline Eucomis humilis Baker & 47.1 & & & Drakensberg, KZN & NBG 291/57 \\
\hline Eucomis humilis Baker & 48.2 & & & Drakensberg, KZN & NBG 222/99 \\
\hline Eucomis humilis Baker & 48.1 & & & Drakensberg, KZN & NBG 837/82 \\
\hline Eucomis humilis Baker & 48.5 & & & Hort. & J. des Brisay \\
\hline Eucomis humilis Baker & 47.3 & & & Sani Pass, KZN & van Jaarsveld 6596 \\
\hline Eucomis humilis Baker & 47.7 & & & Hort. & J. des Brisay \\
\hline Eucomis humilis Baker & 47.8 & & & Cathcart, E. Cape & C. McMaster s.n. \\
\hline Eucomis montana Compton & 47.6 & 48.7 & 0.9 & Vryheid, KZ Natal & D. Govender s.n. \\
\hline Eucomis montana Compton & 48.4 & & & Hort. & J. des Brisay \\
\hline Eucomis montana Compton & 48.3 & & & Hort. & L. Nieuwoudt \\
\hline Eucomis montana Compton & 49.8 & & & Tafelberg KZ Natal & J. des Brisay \\
\hline Eucomis montana Compton & 49.6 & & & Swaziland & H. Hay \\
\hline Eucomis autumnalis 'Sparkling Burgundy' & 46.1 & & & Hort. & Plant Delight Nurs. \\
\hline Eucomis comosa 'Reuben' & 46.6 & & & Kirstenbosch BG & E. Welsh \\
\hline Eucomis comosa 'Coco' & 46.4 & & & Kirstenbosch BG & E. Welsh \\
\hline Eucomis comosa 'Concolor' & 47.3 & & & Hort. & J. des Brisay \\
\hline Eucomis comosa var. striata 'Tugela Jade' & 48.2 & & & Kirstenbosch BG & E. Welsh \\
\hline Eucomis comosa var. striata 'Can Can' & 46.3 & & & Kirstenbosch BG & E. Welsh \\
\hline
\end{tabular}

forms with striking burgundy-pink blooms whose leaves are purplish-burgundy when grown in full sun (Duncan 2007). Its DNA 2C value is $47.6 \mathrm{pg}$.

The subsp. clavata (Baker) Reyneke has, as its name suggests, clavate scapes, although not always (Reyeneke 1980). The description calls for a large leaved plant with a comparable rather short inflorescence of 7-13 cm. Further, it has hard, double-layered pericarps contrary to the thin pericarp of ssp. autumnalis. It is widespread in the north and northeast of South Africa, and its DNA 2C value is $46.9 \mathrm{pg}$.

\section{Eucomis comosa (Houtt.) Wehrh.}

The sweet-scented E. comosa (syn: E. punctata), is found from the Eastern Cape to Limpopo in northern South 


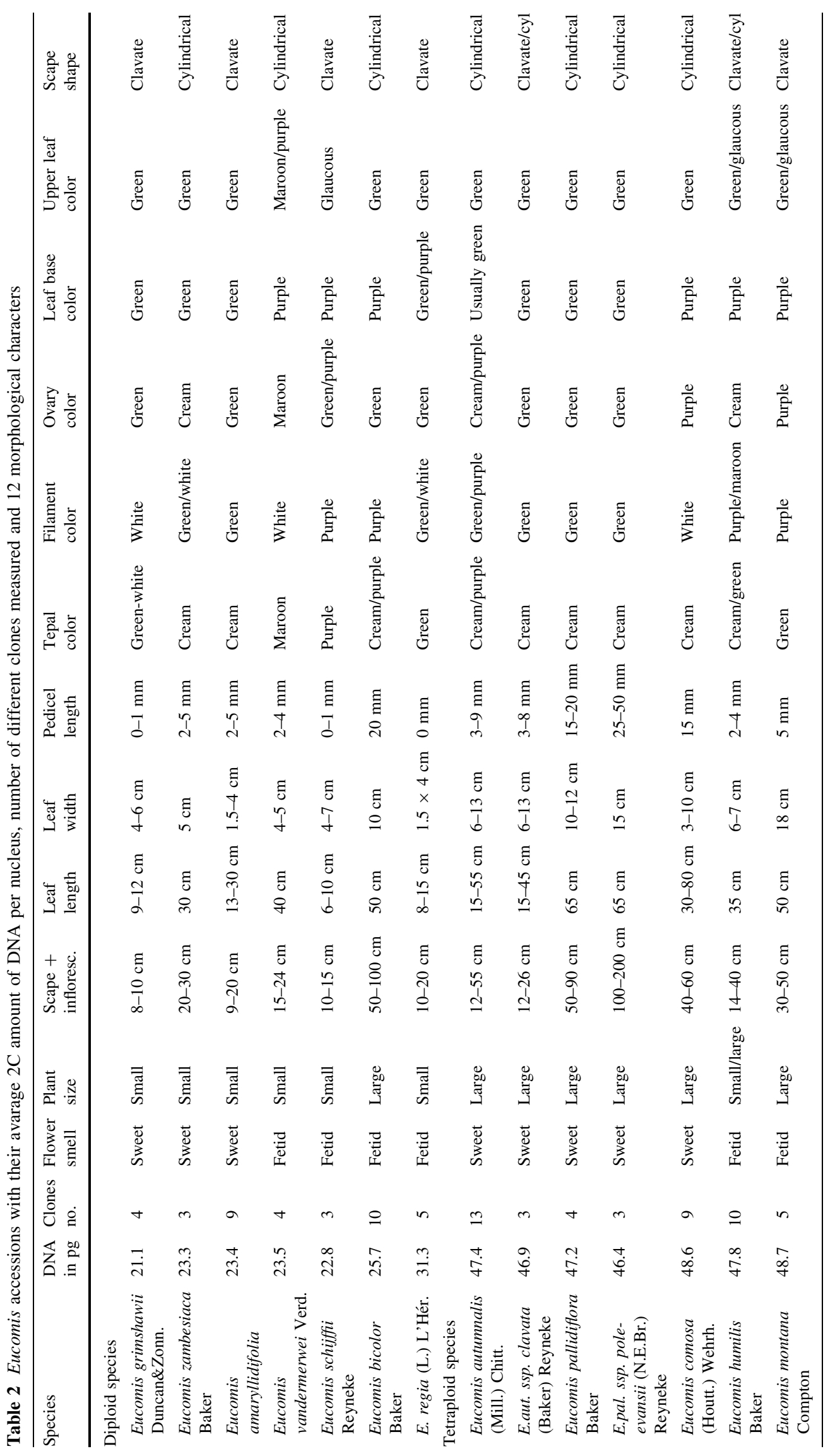


Africa. The typical variety occurs in a range of dry to moist habitats, while the var. striata (Donn) Wild. is confined to swampy conditions, having distinctive stripes instead of spots on the outer leaf bases. It has cylindrical scapes, and the DNA 2Cvalue of E. comosa var. comosa is $48.6 \mathrm{pg}$. Surprisingly, one of the three accessions received as var. striata turned out to be a pentaploid with $61.0 \mathrm{pg}$.

\section{Eucomis pallidiflora Baker}

Giant within the group, the plain green E. pallidiflora subsp. pallidiflora is native to wetland marshes in the Eastern Cape, Lesotho and KwaZulu-Natal. It has sweetsmelling and greenish-cream flowers, and cylindrical scapes. Its DNA $2 \mathrm{C}$ value is $47.7 \mathrm{pg}$. Eucomis pallidiflora subsp. pole-evansii, previously E. pole-evansii (Brown 1918), occurs further north in Mpumalanga and Swaziland and is even more robust than subsp. pallidiflora, its racemes reaching up to $2 \mathrm{~m}$ high or more. Its DNA 2C-value is $46.4 \mathrm{pg}$, but this difference falls within the standard deviation (Table 1). Both subspecies are further characterized by their long pedicels of $15-50 \mathrm{~mm}$.

\section{Eucomis humilis Baker}

Eucomis humilis has greenish-cream, foul-smelling flowers on a cylindrical or clavate scape. We found E. humilis, despite its often small size, to be tetraploid with a DNA 2C value of $47.8 \mathrm{pg}$.

A perusal of W.F. Reyneke's thesis on Eucomis and examination of herbarium material annotated by him shows that E. humilis is an extremely variable species, which has given rise to some confusion among gardeners. Eucomis humilis grows to $40 \mathrm{~cm}$ high and occurs in small groups at high altitude in moist grassland below rocky overhangs in northeastern Lesotho and western KwaZulu-Natal. It comprises several distinct forms, including a short form with pale green flowers arranged tightly together on a short, compact inflorescence that is shorter than the length of the leaves, and a very different-looking, robust form with larger, cream-coloured flowers arranged more loosely on a much longer inflorescence, a portion of which overtops the leaves. The flowers of the green form have pinkish-maroon filaments, but in the cream form they are broader and deep purple. The leaves of both forms are broadly lance-shaped with crisped or undulate margins, and are usually heavily spotted with maroon or purple on the undersides, as well as on the scape. The leaves of the short form are bright green, while those of the robust form are much larger and dark green with a purple tinge, with deep purple margins. According to Reyneke (1972), these two forms occur in association in the wild, and at certain localities a number of intermediate forms occur between the two extremes, making it difficult to assign taxonomic rank to any particular form. In addition to these, a dwarf form exists, having rather short green leaves with purple spotting on the undersides, and short creamy-green inflorescences that appear above the leaves.

It has become clear that a robust, cream-flowering form of E. humilis has for years been incorrectly listed and illustrated by nurseries in the Northern Hemisphere as E. montana Compton. According to the literature and herbarium material, the true $E$. montana has a more northerly distribution, with green flowers, purple ovaries and broader leaves (see the description below).

\section{E. montana Compton}

A native of Swaziland, the northeastern Free State and eastern Mpumalanga in South Africa, E. montana is a robust plant up to $50 \mathrm{~cm}$ high with very large, semi-erect, ovate leaves that are spotted on the underside towards the base, and usually have flat margins (Compton 1967). It has clavate scapes and green flowers with purple/dark-brown filaments, and the rather short inflorescence is produced well below the tips of the leaves. It has a DNA 2C value of $48.7 \mathrm{pg}$. Eucomis montana grows in large groups at high altitude on rocky mountain slopes in partial shade of boulders, flowering in midsummer. We are aware of only one authentic illustration, a watercolor painting (Fabian 1982), and the species is very rare in cultivation. It is very similar to large forms of E. humilis, including its fetid flowers. The only difference seems to be the green tepals and the purple ovary.

\section{Discussion}

Nuclear DNA content was measured in 85 accessions of Eucomis. The ploidy results are generally in agreement with the results of Reyneke (see below for the exceptions). It cannot be excluded that, as has been stated by Reyneke and Liebenberg (1980), the fact that Eucomis could have $30 / 32$ or $60 / 64$ chromosomes might indicate that aneuploidy may play a role. Four dwarf species with 22.6, 23.3, 23.4 and $23.5 \mathrm{pg}$ had very close values. The same is true for all the tetraploid plants varying only from 46.4$48.6 \mathrm{pg}$, well within the range of variation. Therefore, it was often not possible based on the DNA $2 \mathrm{C}$ value alone to subscribe an unknown accession to a certain species. Exceptions are E. bicolor with $25.7 \mathrm{pg}$ and E. regia with $31.3 \mathrm{pg}$ and the new species E. grimshawii with $21.1 \mathrm{pg}$.

Moreover, very few morphological characters are useful in Eucomis. Those that have been investigated are compared in Table 2. Genome size as investigated here (Tables 1, 2) complements the work based mainly on morphological characters of (Reyneke 1972). 
The evolutionary origin of the tetraploid species

Ploidy seems to play a bigger role than envisioned in the speciation of Eucomis. Earlier cytological investigation of Eucomis has shown that about half the species are diploid (Reyneke and Liebenberg 1980), and this is confirmed here (Table 1). Only in E. comosa was a pentaploid found.

Polyploid tulips are concentrated in the middle and upper mountains, whereas the diploids are mainly found in the deserts and lower mountains (Botschantzeva 1962). The opposite seems true for Eucomis with all the diploid species (except certain forms of E. regia) occurring high up in the mountains. In most cases polyploidy is not an argument (any longer) to assign a taxon specific status (Woods and Bamford 1937). The origin of the tetraploid species of Eucomis is unknown so far. Reyneke and Liebenberg (1980) state that all tetraploids are allotetraploids. These allotetraploids must be derived from two different diploid parents. Moreover, it seems likely that plants with sweet smells have pollinators different from those with fetid smells. Besides, sweetsmelling E. autumnalis, E. pallidiflora and E. comosa have morphologically most in common with sweet-smelling E. amaryllidifolia. So if these sweet tetraploids have two different sweet diploid parents, they are likely to be: E. amaryllidifolia and E. zambesiaca. The very large coma bracts and lower amount of nuclear DNA of the sweetscented E. grimshawii do not seem to fit in here. Different forms of each diploid species and local adaptations might have resulted in the end in "different" tetraploid species. The two fetid tetraploids E. humilis and E. montana are morphologically most similar to E. bicolor. Therefore, their parents could be the fetid E. bicolor and E. schijffii. The heavily maroon spotted upper leaf surfaces of E. vandermerwei seem to exclude it as a parent. Just doubling E. bicolor ( $\rightarrow 51.4 \mathrm{pg}$ ) would give too high a value, unless genome downsizing has taken place, as often happens in tetraploids. The above hypotheses are not in contradiction with the amounts of nuclear DNA as measured here.

\section{Conclusions}

Flow cytometry can be considered as a quick and useful method to produce a systematic data source. Moreover, it can be used to investigate imported bulbs, precluding the need to grow them to maturity for identification purposes. The difference between the highest and lowest DNA contents for the diploids is about $10 \mathrm{pg}$. This $50 \%$ increase in DNA content without changing the number of chromosomes must be the result of a vast number of genomic changes. Depending on the size of the total genome, $1 \mathrm{pg}$ amounts to several thousand genes. Therefore, flow cytometry is not a one-character-based taxonomy as the largest genome contains roughly
$10^{10}$ more base pairs than the smallest and has chromosomes that are on average 50\% longer. The data presented here for DNA content agree in most respects with the most recent classification of Eucomis. Flow cytometry as a taxonomic and diagnostic tool is applicable even in the case of dormant bulbs or sterile plants, and therefore has applications for conservation monitoring.

Acknowledgments We thank Cameron McMaster for making a special effort to collect the type material of Eucomis grimshawii, for providing a habitat photograph of the plant and for sharing his knowledge of Eucomis in the Eastern Cape. B.Z. thanks J.F. Veldkamp for correcting the Latin diagnosis.

Open Access This article is distributed under the terms of the Creative Commons Attribution Noncommercial License which permits any noncommercial use, distribution, and reproduction in any medium, provided the original author(s) and source are credited.

\section{References}

Baker JG (1878) New garden plants: Eucomis amaryllidifolia and Eucomis bicolor. Gard Chron 10:492

Baker JG (1886) Eucomis zambesiaca. Gard Chron 25:9

Baker JG (1887) New or noteworthy plants: Eucomis pallidiflora. Gard Chron (2): 154

Baker JG (1895) Eucomis humilis. Bull Misc Inform Kew 152

Botschantzeva ZP (1962) Tulips: taxonomy, morphology, cytology, phytogeography, and physiology. English translated edition by HQ Varekamp (1982) p. 1-230. Balkema, Rotterdam

Brown NE (1918) New or noteworthy plants: Eucomis pole-evansii. Gard Chron III 63:185

Chittenden FJ (1951) Eucomis autumnalis. Roy Hort Soc Dict Gard 2:787

Compton RH (1967) Plantae Novae Africanae: Eucomis montana. J S Afr Bot 33:293-294

Compton J (1990) Eucomis L'Héritier. The Plantsman 12-3:129-139

Dillenius JJ (1732) Hortus Ethamensis. Sumptibus Auctoris, London

Dolezel J, Bartos J, Voglmayer H, Greilhuber J (2003) Nuclear DNA content and genome size of trout and human. Cytometry 51a: $127-128$

Duncan GD (2007) Lesser known Eucomis. The Plantsman 6:98-103

Fabian A (1982) Transvaal Wild Flowers: 26 (plate 8b). Macmillan Publication, USA

Govaerts R (2006) World checklist series RBG Kew, UK: genus Eucomis. http://apps.kew.org/wcsp/qsearch.do77

Greilhuber J (1979) Evolutionary changes of DNA and Heterochromatin amounts in the Scilla bifolia Group (Liliaceae). Plant Syst Evol Suppl 2:263-280

Greilhuber J (1998) Intraspecific variation in genome size: a critical reassessment. Ann Bot 82:27-35

Greilhuber J (2005) Intraspecific variation in genome size in angiosperms, identifying its existence. Ann Bot 95:91-98

Leitch I, Chase MW, Bennett MD (1998) Phylogenetic analysis of DNA C-values provides evidence for a small ancestral genome size in flowering plants. Ann Bot 82(Suppl. A):85-94

Ohri D (1998) Genome size variation and plant systematics. Ann Bot 82(Suppl. A):750-812

Reyneke WF (1972) 'n Monografiese studie van die genus Eucomis L'Hérit. in Suid Afrika. Department of Botany, University of Pretoria. unpublished Msc thesis 
Reyneke WF (1976) A new species of Eucomis L'Hérit. (Liliaceae) from South Africa. J S Afr Bot 42-4:361-364

Reyneke WF (1980) Three subspecies of Eucomis autumnalis. Bothalia 13:140-142

Reyneke WF, Liebenberg H (1980) Karyotype analysis of the genus Eucomis (Liliaceae). J S Afr Bot 46-4:355-360

Taylor JLS, van Staden J (2001) COX-1 inhibitory activity in extracts from Eucomis L'Herit' species. J Ethnopharm 75:257-265

Tiersch TR, Chandler RW, Wachtel SSM, Ellias S (1989) Reference standards for flow cytometry and application in comparative studies of nuclear DNA content. Cytometry 10:706-710

Verdoorn IC (1944) Eucomis vandermerwei. Fl Pl S Africa 24:t. 955

Woods MW, Bamford R (1937) Chromosome morphology and number in Tulipa. Am J Bot 24:174-184

Zonneveld BJM (2001) Nuclear DNA contents of all species of Helleborus discriminate between species and sectional divisions. Plant Syst Evol 229:125-130

Zonneveld BJM (2003) The systematic value of nuclear DNA content in Clivia. Herbertia 57:41-47

Zonneveld BJM (2008) The systematic value of nuclear DNA content for all species of Narcissus L. (Amaryllidaceae). Plant Syst Evol 275:109-132
Zonneveld BJM (2009) The systematic value of nuclear genome size for all species of Tulipa L. (Liliaceae). Plant Syst Evol (in press)

Zonneveld BJM, Duncan GD (2003) Taxonomic implications of genome size and pollen color and vitality for species of Agapanthus L'Héritier (Agapanthaceae). Plant Syst Evol 241:115-123

Zonneveld BJM, Duncan GD (2006) Genome size for the species of Nerine Herb. (Amaryllidaceae) and its evident correlation with growth cycle, leaf width and other morphological characters. Plant Syst Evol 257:251-260

Zonneveld BJM, Van Iren F (2001) Genome size and pollen viability as taxonomic criteria: application to the genus Hosta. Plant Biol 3:176-185

Zonneveld BJM, Van Jaarsveld EJ (2005) Taxonomic implications of genome size for all species of the genus Gasteria Duval (Aloaceae). Plant Syst Evol 251:217-227

Zonneveld BJM, Grimshaw JM, Davis AP (2003) The systematic value of nuclear DNA content in Galanthus. Plant Syst Evol 241:89-102 